Letrônica, Porto Alegre, v. 7, n. 1, p. 113-129, jan./jun., 2014

\title{
LISTENING COMPREHENSION AND INDIVIDUAL DIFFERENCES IN WORKING MEMORY CAPACITY IN BEGINNING L2 LEARNERS
}

\author{
COMPREENSÃO ORAL E DIFERENÇAS INDIVIDUAIS NA CAPACIDADE DE \\ MEMÓRIA DE TRABALHO EM APRENDIZES INICIANTES DE L2
}

\begin{abstract}
The objective of present study was to investigate whether individual differences in working memory capacity of L2 learners predict listening comprehension performance in a proficiency exam. Participants included two groups of adult students (24 students in total) of English as an L2. In the first part of the experiment, the 24 adult students performed a Listening Mock test. In the second part of the experiment the 24 adult students performed a working memory span test. The hypothesis of the study was that individual differences in working memory capacity of L2 learners would predict listening comprehension performance in a proficiency test. The hypothesis was confirmed. Individual differences in working memory capacity predicted listening comprehension performance, showing that the larger the working memory storage capacity is, the higher the scores in listening comprehension tasks will be.

Keywords: Individual differences; Listening comprehension; Working memory capacity; L2 low-proficiency learners.

Resumo: 0 objetivo do presente estudo foi investigar se as diferenças individuais na capacidade de memória de trabalho de aprendizes de inglês como segunda língua (L2) poderiam prever o desempenho em tarefas de compreensão oral em um exame de proficiência. Dois grupos de aprendizes adultos de Inglês como L2 (24 alunos no total) participaram deste estudo. Na primeira parte do experimento os 24 participantes realizaram um teste simulado de listening (parte de um teste padronizado e internacional) para a obtenção de seus escores. Na segunda parte do experimento os 24 participantes realizaram um teste que mede a capacidade de memória de trabalho (BAMT). A hipótese do estudo era que as diferenças individuais na capacidade de memória de trabalho de aprendizes de inglês como L2 seriam preditoras de desempenho em tarefas de compreensão oral no exame de proficiência. A hipótese foi confirmada. As diferenças individuais na capacidade de memória de trabalho foram preditoras de desempenho nas tarefas de compreensão oral do exame, demonstrando que quanto maior a capacidade de armazenamento da memória de trabalho, maior será o escore dos aprendizes em tarefas de compreensão oral.
\end{abstract}

Aline Fay

Augusto Buchweitz**

Palavras-chave: Diferenças individuais; Compreensão oral; Capacidade de memória de trabalho; Aprendizes de inglês como L2 com baixa proficiência.

\footnotetext{
${ }^{*}$ PhD student and Professor at Pontifical Catholic University of Rio Grande do Sul.

** Professor at Pontifical Catholic University of Rio Grande do Sul - Graduate Program in Linguistics.
} 


\section{Introduction}

The goal of the present study was to investigate individual differences in listening comprehension in L2 learners. Listening comprehension plays an important role in everyday human communication and it is a key skill for second language learning, especially in situations of immersion in L2 or in formal educational settings that seek to engage students in communication activities. Listening provides the auditory input that is essential for language acquisition and it enables learners to interact in spoken communication.

Listening comprehension is automatic for native speakers and for highly proficient second language learners. The classical criteria for establishing that a behavior is automatic are that the stimuli associated with the behavior almost always elicit the behavior (i.e. humans lack volitional control); and that the process can be successfully executed while a secondary task is being performed (SCHNEIDER; SCHIFFRIN, 1977). Thus listening comprehension in L1 and in proficient L2 listeners falls under the category of an automatic process.

Individual differences provide an understanding of the variability in human skills that help predict performance in such higher-level tasks as listening comprehension. Individual differences may be measured using psychometric measures of human abilities, personality traits, and knowledge, for example. In this sense, working memory is a construct that helps understand capacity limitations to process and store information ${ }^{1}$. Individual differences, in this sense, may help teachers inform their choice of listening comprehension tasks to their students by taking into consideration not only linguistic factors such as the listener's language proficiency, but also cognitive factors, such as the learners' limited ability to simultaneously process and store information.

The goal of the present study was to investigate whether individual differences in working memory capacity of L2 low-proficiency learners predict listening

\footnotetext{
1 The term 'working memory' refers to a brain system that provides temporary storage and manipulation of the information necessary for such complex cognitive tasks as language comprehension, learning, and reasoning (BADDELEY, 1999).
} 
comprehension performance in a proficiency exam (Key English Test - KET2). The hypothesis is that individual differences in working memory capacity will predict listening comprehension performance in the standardized test.

\section{Individual Differences and Working Memory Capacity}

There is a consensus among researchers that working memory is involved in the performance of a number of cognitive tasks (e.g., BADDELEY, 2009; CONWAY et al., 2008; ENGLE, 2002; JUST; CARPENTER, 1992 among many others). Working memory span tests (DANEMAN; CARPENTER, 1980, for instance) provide a measure of working memory capacity that reliably predict performance in higher-level cognitive tasks. In general, individuals with higher working memory capacity perform better on these tasks than individuals with lower capacity (TOMITCH, 2003; FORTKAMP, 2000).

According to Baddeley (2009), the limited capacity approach to working memory was leveraged by a study by Daneman and Carpenter (1980); the authors proposed a measure of working memory span that predicts reading comprehension performance. In the span test, the processing component of working memory is assessed by reading sentences; the storage component of working memory, in turn, is assessed by asking participants to memorize and later retrieve the final word of each sentence read. Just and Carpenter (1992) stated that the nature of a person's language comprehension depends on his or her working memory capacity. Individuals vary in the amount of processing and storage capacity they have available for meeting the computational demands of language processing. This conceptualization predicts quantitative differences among individuals in the speed and accuracy with which they comprehend language.

According to Just and Carpenter (1992), individual differences in working memory capacity for language can account for qualitative and quantitative differences among students in several aspects of language comprehension. One aspect is syntactic modularity, showing that the larger working memory capacity of some individuals facilitates interaction between syntactic and pragmatic information. Another aspect is

\footnotetext{
${ }^{2}$ Key English Test (KET) is a basic level qualification that shows you can use English to communicate in simple situations and have achieved a good foundation in learning English. http://www.cambridgeesol.org/exams/ket/index.html.
} 
syntactic ambiguity (for instance, "I saw the man with the binoculars" and "They are hunting dogs"). The higher capacity of some individuals allows them to maintain multiple interpretations.

\section{Working memory and L2 Learning}

Though most research on individual differences focuses on first language comprehension performance, recent studies have addressed the relationship between working memory capacity and L2 skills. These studies have focused on reading comprehension, on syntactic acquisition and comprehension, and on speech production (TOMITCH, 2003; FORTKAMP, 2000). Studies of individual differences in WM (working memory) performance among L2 learners provide promising initial support for the view that WM capacity is related to performance in L2 comprehension tasks: individual differences in L2 reading skill were highly correlated with L2 WM span (MIYAKE; FRIEDMAN, 1998, in HEALY; BOURNE, 1998).

In a study by Harrington and Sawyer (1992), 32 native Japanese speakers learning English as an L2 were asked to complete an English and Japanese version of the reading span test, along with two subsections of the Test of English as a Foreign Language (TOEFL). Results showed that readers with higher L2 reading span scores had a better performance on the subsections of the TOEFL tested; the improved performance was associated with correlation coefficients of .57 (grammar section) and .54 (reading and vocabulary section). In the same vein, Harrington (1991) investigated the extent to which vocabulary and grammatical knowledge are factors for the relationship between L2 working memory capacity and L2 reading comprehension measures. The study showed a significant correlation between working memory capacity and scores on L2 vocabulary, grammar, and L2 reading measures. These studies suggest an association between working memory capacity and L2 learners' performance at the word and sentence levels.

WM is also associated with the process of L2 learning itself. According to Miyake and Friedman (in HEALY; BOURNE, 1998), not much research has directly addressed the issue of WM and L2 learning; however, some studies provide preliminary answers as to how WM influences the speed and quality of L2 learning. A study carried out by Ando et 
al (1992; in HEALY; BOURNE, 1998) showed the advantage of a higher working memory capacity in L2 learning. Basic English was taught for 20 hours to Japanese $6^{\text {th }}$ graders. The learners' reading and listening spans in L1, before the English instructions, were the strongest predictors of their post test performance in L2 (.60 for reading span and .72 for listening span). The results suggest that higher working memory capacity may be associated with more effective L2 learning. This tentative conclusion is consistent with recent cognitive studies. The studies demonstrated that higher WM capacity generally facilitates the process of skill learning and knowledge acquisition; higher capacities make it easier for learners to keep all the relevant pieces of information simultaneously active within WM (ORTEGA, 2009).

\section{Methods}

\subsection{Experiment Design}

The experiment was divided into three parts. First, in the listening comprehension task, 24 adult, students of English as a foreign language (10 students control group and 14 students - experimental group), performed a complete Mock test of the Cambridge Exam KET. Next, the 24 participants performed a working memory span test (BAMT-UFMG; Bateria de avaliação da Memória de Trabalho: Alcance na apreensão na escrita ${ }^{3}$ ). Finally, all data collected in the listening comprehension task and working memory span task was coded and analyzed.

\subsection{Participants}

Twenty-four adult students of English as a foreign language (18 females and 6 males), mean age 32 (SD = 10.44; range 20-52 years), were recruited for the study. All students were Brazilian native speakers of Portuguese and studying English in an English Language Course in Porto Alegre, Brazil. Participants were L2 low proficiency learners (students who apply to study in this English course have to take a Placement

\footnotetext{
${ }^{3}$ BAMT- UFMG (Bateria de avaliação da Memória de Trabalho: Alcance na apreensão na escrita) is a working memory span test whose aim is to measure subjects' capacity of storing and processing information.
} 
Test ${ }^{4}$, which consists of three parts: Grammar and Vocabulary, Writing and Speaking. Participants were placed in the same level: Elementary) and belonged to a level in which students are prepared to take the Cambridge Exam KET. The level of schooling of participants was: 17 participants had a university-level degree and 7 participants were undergraduate students.

Each participant gave signed informed consent approved by the Pontifícia Universidade Católica do Rio Grande do Sul research ethics committee (process number CAAE: 05829112.3.0000.5336).

\subsection{Materials}

The listening comprehension task ${ }^{5}$ included a complete listening task from the Cambridge proficiency exam KET. Working memory capacity was measured using the BAMT - UFMG test (Bateria de avaliação da Memória de trabalho) ${ }^{6}$.

\section{Listening comprehension task}

The control group was evaluated first (10 students in total), and then the experimental group (14 students in total). Classroom seats were arranged in rows (the seating arrangement is usually a horseshoe). It was explained that students would be taking a mock test for the KET listening test; the mock test is part of the school's regular procedures. However, it was also explained to the students that the results of the test would be used in a study on individual differences and listening comprehension. The participants were given information about the research, signed the informed consent form, and were allowed some time to read and ask questions concerning the study and the form.

All data were collected individually. Each subject received a booklet with five tasks (25 questions in total) to answer. The instructions were read by the teacher for the five parts of the listening test; when students were ready, the audio was played. The test lasted 30 minutes.

\footnotetext{
4 The Placement Test is fully described in Fay (2012).

5 The listening comprehension task is fully described in Fay (2012).

${ }^{6}$ The description of the Working Memory Span Test (BAMT) can be found in Wood et al (2001).
} 
The working memory span test used was the BAMT - UFMG (Bateria de avaliação da Memória de trabalho). The test evaluates working memory capacity based on three interrelated tests: processing speed or efficiency, temporary storage and coordinative capacity. The test was formally validated with 832 participants; the study indicated that the test has reliability and validity and it is adequate for use in Brazil.

We selected a working memory span test in Portuguese, rather than in English, to eliminate the confound of L2 proficiency affecting the result of the working memory span test. In other words, L2 comprehension difficulties affecting the results differently for different participants (evidently, if L2 proficiency was homogenous, the test could be in English if the effects of proficiency were also homogenous, which is not the case).

Below we have examples of each test used to evaluate working memory capacity.

\begin{tabular}{|lcc|}
\hline \multicolumn{3}{|c|}{ Alcance de computação na escrita } \\
\hline \multicolumn{1}{|c|}{ Quem? } & \multicolumn{1}{c|}{ Pôs o quê? } & Quem? \\
( ) Ogalo & ( ) O ovo & ( ) O namorado de Eunice \\
( ) Juca & ( ) O cachorro & ( )João \\
( ) Óculos & ( ) O vento & ( ) O tio de Eunice \\
\hline
\end{tabular}

\begin{tabular}{|c|c|c|}
\hline \multicolumn{3}{|c|}{ Lista de palavras } \\
\hline FOTO & RATO & NOTA \\
JILÓ & DOCE & ÉGUA \\
COLA & BONÉ & $P A ́$ \\
\hline
\end{tabular}

\footnotetext{
Compreensão de frases

Os meninos brincaram muito de peteca e de bola. Quem?

( ) À janela

( ) Paulo

( ) Os meninos

Os vaqueiros sabem que o patrão gosta de gado.

Quem gosta de gado?

( ) Os homens

( ) O patrão

( ) A natureza
} 
All data was collected individually, each subject received a booklet entitled "Livro de Tarefas e Instruções para Aplicação em Grupos". We explained to the participants that the test was divided into 3 parts and that each part would be explained separately. The first part of the test is entitled "Alcance de apreensão na escrita". The aim of this test is to answer questions and simultaneously memorize words. In order to help participants understand the task we prepared 3 questions similar to the ones used in the BAMT and gave them 3 alternatives for each question.

\subsection{Data analysis}

First, a descriptive analysis of the data was conducted; it provided an overview of the groups' performance in the tasks mentioned above. The minimum, maximum, the average scores and the standard deviation for each group were provided by the analysis.

To analyze the relationship between Working Memory and Listening Comprehension, a nonparametric test designed to determine the degree of association between two variables " $\mathrm{x}$ " and " $\mathrm{y}$ " entitled "Regression and Correlation analyses" described by Triola (1999, p. 88) was used. Regression and correlation are two closely related techniques that involve a form of estimation. The correlation and regression analyses identify whether two or more variables are associated in a given data universe. A simple linear regression is an attempt to establish a mathematical equation that describes the linear relationship. In this sense, these analyses will indicate whether performance in the listening comprehension test could be associated with working memory capacity.

\section{Results and discussion}

The results indicate that individual differences in working memory capacity predicted listening comprehension performance in the standardized test $(r=.66$ and $p<0.0002245$ for the WM task "Alcance de apreensão na escrita", $\mathrm{r}=.38$ and $\mathrm{p}<.031$ for the sentence Comprehension task "Compreensão de Frases", and $r=.87$ and $p<.0000001$ for the list of words task "Lista de Palavras"). 
The ability to maintain and process information, as measured by the working memory span test applied in the study, predicts the performance in the skills associated with listening comprehension as tested in the exam. This result corroborates previous studies that show that individuals with low scores on complex working memory span tasks (low WMC individuals) are poorer at actively maintaining information than are individuals who score high on complex working memory span tasks (high WMC individuals), (UNSWORTH; ENGLE, 2007).

According to Craik (2000) working memory is involved in tasks that allow us to make sense of what we read, listen and speak and is essential for mental calculation and problem-solving, reasoning, and planning. In addition, WM tasks involve the manipulation, storage, and transformations of held material for a short period of time which is the aim of the test "Alcance de apreensão na escrita."

Table 1 presents the participants' scores for the Working Memory test in comparison to participants' scores for the listening comprehension task. Figure 1 shows graph presenting the Regression and Correlation analyses based on the results.

Table 1 -Working Memory Test "Alcance de apreensão na escrita" and Listening Comprehension Test: Average Score and Standard Deviation

\begin{tabular}{lll}
\hline & Working memory (SD) & Listening Comprehension (SD) \\
\hline Control & $10.2(6.2)$ & $56.0(17.9)$ \\
Experimental & $9.8(10.1)$ & $66.0(17.2)$ \\
\hline
\end{tabular}

Figure 1: Regression and Correlation Analyses:

Working Memory Test "Alcance de apreensão na escrita” and Listening Comprehension Test

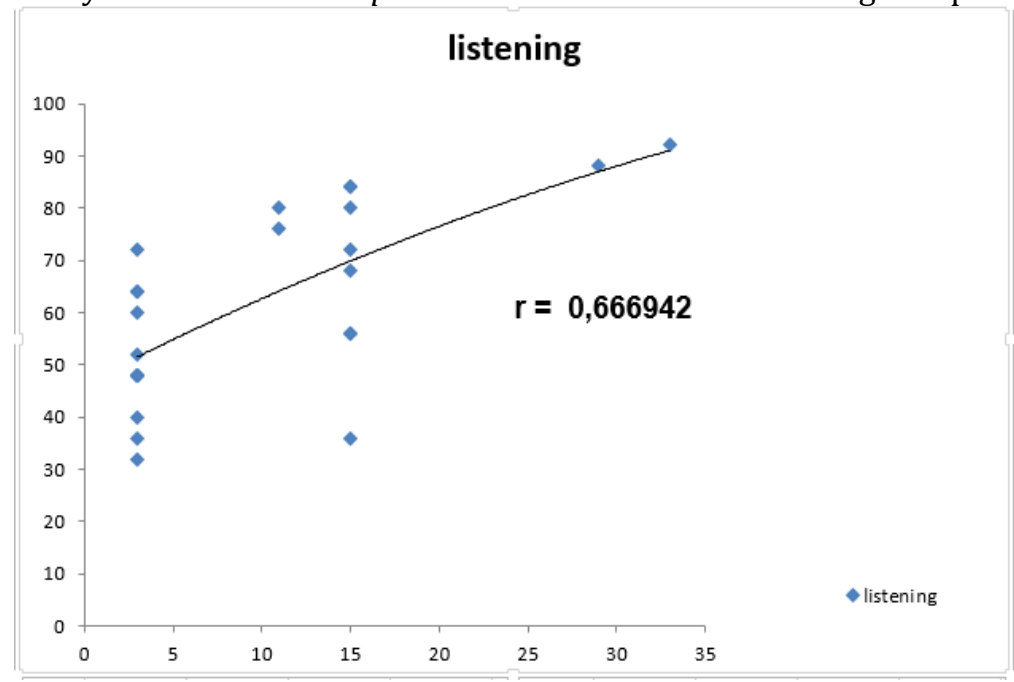




\subsection{Speed of processing and listening comprehension}

The test of speed of processing also correlated with performance in the listening comprehension task. The results suggest a significant correlation between the scores and the test $(r=.38$ and $\mathrm{p}<.05)$. According to Salthouse (1996), speed of processing is a basic cognitive or brain process that subserves many other higher-order cognitive domains. Among those higher domains is executive functioning, a somewhat broad construct that involves the organization of behaviors and behavior responses, selective attention of pertinent information and suppression of unnecessary information, and maintenance and shifting of cognitive sets. According to the author, cognitive performance is degraded when processing is slow because relevant operations cannot be successfully executed (limited time) and because the products of early processing may no longer be available when later processing is complete (simultaneity). This explains why the speed processing task was perceived as one the most difficult tasks by the participants. Not only did participants have to listen, process and answer a question, but they also have to memorize the last word the listened.

Table 2 shows the scores for the Working Memory test "Compreensão de Frases". Figure 2 shows a graph presenting the Regression and Correlation analyses based on the results.

Table 2 - Working Memory Test “Compreensão de Frases” and Listening Comprehension: Average Score and Standard Deviation

Working memory (SD) Listening Comprehension (SD)

\begin{tabular}{lll}
\hline Control & $42(6.8)$ & $56(17.9)$ \\
Experimental & $48.57(7.66)$ & $66(17.2)$
\end{tabular}


Figure 2: Regression and Correlation Analyses: Working Memory Test “Compreensão de Frases" and Listening Comprehension

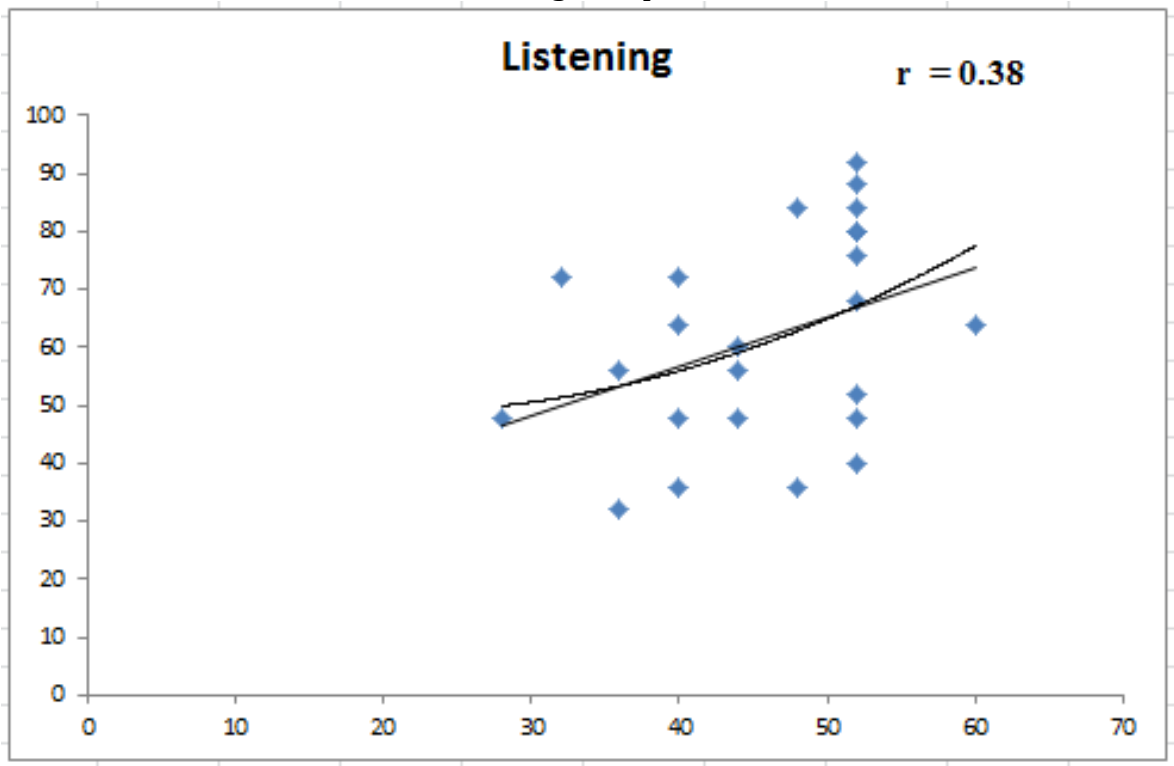

\subsection{Word List and Listening Comprehension}

The aim of the working memory task "Lista de Palavras" is to assess short-term memory for an increasing list of words. Each list started with 3 words (3 columns of 3 words each) and increased up to 6 words ( 6 columns of 6 words each), which was the maximum level reached by all the participants. Below we have an example of 2 lists of words (one with 3 words in each column and another with 4 words in each column).

\begin{tabular}{l|c|c|}
\hline FOTO & RATO & NOTA \\
JILÓ & DOCE & ÉGUA \\
COLA & BONÉ & \\
\hline \multicolumn{2}{|c|}{} \\
\hline BOTE & GALO & MAÇO \\
JACA & RÉGUA & ANGÚ \\
MARÉ & DIA & REMO \\
REDE & CIPÓ & GIBI \\
\hline
\end{tabular}

The results indicate that individual differences in working memory capacity predict differences in listening comprehension performance in the KET tasks $r=.8735$ and $\mathrm{p}<.0001$. 
Table 3 shows the participants' scores for the working memory test in comparison to the participants' scores for the Listening Pre-test. Figure 3 shows a graph presenting the Regression and Correlation analyses based on the results.

Table 3 - Working Memory Test "Lista de palavras" and Listening Comprehension: Average Score

Working memory (SD) Listening Comprehension (SD)

\begin{tabular}{lll}
\hline Control & $12.7(5.03)$ & $56(17.9)$ \\
Experimental & $14.57(8.26)$ & $66(17.2)$ \\
\hline
\end{tabular}

Figure 2: Regression and Correlation Analyses:

Working Memory Test "Lista de palavras" and Listening Comprehension

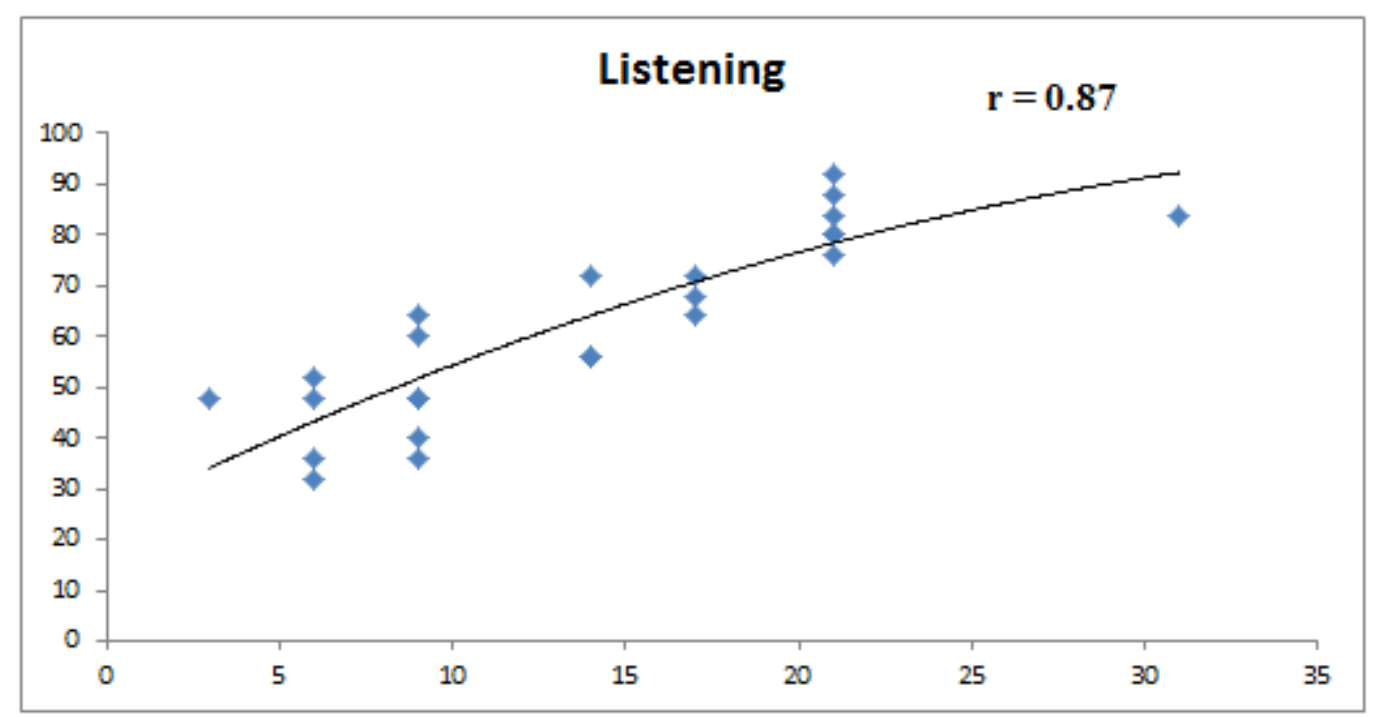

Individual differences in working memory capacity predicted listening comprehension performance in the KET tasks $r=.87$ and $p<.0001$.

Different from the listening span task, the list of words task ("lista de palavras") does not require the storage and processing of information at the same time. For the task "Lista de Palavras," participants were supposed to store information only. The first studies using list of words were the studies carried out under the free-recall paradigm, in which participants were presented with lists of unrelated words and asked to recall as 
many words as possible in any order (different from the BAMT, in which participants are presented with lists of unrelated words and asked to recall as many words as possible in the order they are presented). When recall was immediate, these studies consistently showed a recency effect ${ }^{7}$. When recall was delayed, the recency effect disappeared, which led researchers to suggest that for immediate recall items were maintained in a kind of temporary storage, while for delayed recall items were retrieved from a long-term store.

The distinction between short-term memory and working memory is not as simple as it may seem. Miller et al. (1960) used the term "working memory" to refer to temporary memory from a functional standpoint, so from their point of view there is no clear distinction between short-term and working memory. Baddeley and Hitch (1974) were fairly consistent with this definition but overlaid some descriptions on the terms that distinguished them. The authors claimed that short-term memory was a unitary holding place as described by, for example, Atkinson and Shiffrin (1968). When they realized that the evidence actually was consistent with a multi-component system that could not be reduced to a unitary short-term store, they used the term working memory to describe that entire system.

According to participants' reports, the task "Lista de Palavras" was easier than the task "Alcance de apreensão na escrita," because they only had to listen to and memorize a list of words. The majority of the participants claimed to have memorized the words by rehearsing the words over and over again, until they were told to write the list of words down.

Just and Carpenter (1992) state that the nature of a person's language comprehension depends on his or her working memory capacity. The results presented above suggested that individual differences in working memory capacity may predict listening comprehension performance. The results also demonstrated that larger WM capacity generally facilitates the process of skill learning (in this case listening) and knowledge acquisition, by making it easier for learners to keep all the relevant pieces of information simultaneously active within WM, which, according to Daneman and Green (1986), is a process considered crucial for forming a new production rule or putting

\footnotetext{
${ }^{7}$ According to Baddeley (2000, p. 31), recency effect refers to the enhanced recall of the most recently presented items.
} 
together different pieces of relevant information in order to make appropriate inferences.

\section{Conclusions}

The objective of the present study was to investigate whether individual differences in working memory capacity of L2 low-proficiency learners predict listening comprehension performance in the proficiency exam KET.

The hypothesis we intended to confirm was that individual differences in working memory capacity would predict listening comprehension performance in the KET tasks. The results show that the component of working memory measured by the listening span does predict the comprehension performance of learners with the same proficiency level, and therefore, the hypothesis was confirmed. Individual differences in working memory capacity predicted listening comprehension performance in the standardized test. The nature of a person's language comprehension depends on the capacity of a system called working memory (JUST; CARPENTER, 1992). This capacity differs among individuals, and the differences are reliable predictors of performance on higher-level cognitive tasks, such as language comprehension. Individuals with larger working memory capacity perform better on reading tasks than individuals with smaller capacity (FORTKAMP, 2000).

Behavioral studies have shown that listening and reading comprehension are two closely-related skills (JUST; CARPENTER, 1987). Most of the studies concerning working memory are related to reading comprehension and speech production, not listening. Furthermore, these studies usually investigate high-proficiency L2 learners not beginning L2 learners. Therefore, we believe that the present study contributed to research on the relationship between working memory capacity and listening comprehension in beginning L2 learners. The study also corroborates the findings on individual differences in working memory capacity of Daneman and Carpenter (1980) and Just and Carpenter (1992).

Our study suggests the need for further research. According to Ortega (2009), people usually differ in how fast, how well and by what means they learn an L2. The variability in rates, outcomes and processes can be enormous, particularly for the ones 
who begin learning an L2 later in life. Our suggestion is to develop a study whose aim is to investigate whether individual differences in working memory capacity in children and adult students with low proficiency in English as L2 can help predict performance on listening comprehension tasks in proficiency exams. In addition, the study could also investigate whether listening comprehension strategies would help more the adult learners or children to overcome difficulties associated with individual differences in working memory capacity and listening skills.

It is also important for language teachers to be aware of how they can positively influence their students' perception and understanding of listening strategies. Students should be aware of the strategies required to be a "successful listener" and overcome difficulties in proficiency exams, regardless of low working memory capacity and low proficiency in English.

\section{References}

ATKINSON, R. C.; SHIFFRIN, R. M. Human memory: A proposed system and its control processes. In: Spence, K.W.; Spence, J.T. The psychology of learning and motivation (Volume 2). New York: Academic Press, 1968, p. 89-195.

BADDELEY, A. D.; HITCH, G. Working memory. In: G. H. Bower (Ed.), The psychology of learning and motivation (Vol. 8). New York: Academic Press, 1974, p. 47-89.

BADDELEY, A. D. Working memory: The interface between memory and cognition. In: M. Gazzaniga (Ed.) Cognitive Neuroscience: A Reader. Oxford, UK: Blackwell Publishers Ltd. 2000, p. 292-304.

BADDELEY, A. D; ANDERSON, Michael C.; EYSENCK, Michael W. Memória. Artmed, 2009.

CONWAY, A. R. A.; JARROLD C., KANE, M. J., MIYAKE, A.; TOWSE, J. N. Variation in working memory: An introduction. In A. R. A. Conway, C. Jarrold, M. J. Kane, A. Miyake, J. N. Towse. (Eds). Variation in Working Memory. Oxford: Oxford University Press, 2008, p. 3-17.

CRAIK, F. I. M. Age-related changes in human memory. In D. C. Park and N. Schwarz (Eds.), Cognitive Aging: A Prime. Philadelphia: Psychology Press. 2000.

DANEMAN, M.; CARPENTER, P. A. Individual differences in working memory and reading. Journal of Verbal Learning and Verbal Behavior, v. 19, p. 450-466. 1980.

DANEMAN, M.; GREEN, I. Individual differences in comprehending and producing words in context. Journal of Memory and Language, v. 25, p. 1-18. 1986. 
ENGLE, R. W. Working memory capacity as executive attention. Current Directions in Psychological Science, v. 11, n. 1, p. 9-23. 2002.

FAY, A. Listening Comprehension and Working Memory Capacity in Beginning L2 Learners: An Exploratory Study. Dissertação (mestrado em Linguística), PUCRS, 2012.

FORTKAMP, M. Working memory capacity and L2 speech production: an exploratory study. Tese (Doutorado em Linguística), UFSC, 2000.

HARRINGTON, M. Individual differences in L2 reading: Processing capacity versus linguistic knowledge. Paper presented at the Annual Meeting of the American Association of Applied Linguistics. New York, NY, 1991.

HARRINGTON, M.; SAWYER M. L2 Working Memory Capacity and L2 Reading Skill. Studies in Second Language Acquisition, v. 14, p. 25-38, 1992.

JUST, M. A.; CARPENTER, P. A. A capacity theory of comprehension: Individual differences in working memory. Psychological Review, v. 99, p. 122-149, 1992.

MILLER, G. A.; GALANTER, E.; PRIBRAM, K. H. Plans and the structure of behavior. New York, NY: Holt, Rinehard and Winston. 1960.

MIYAKE, A.; FRIEDMAN, N. P. Individual differences in second language proficiency: Working memory as language aptitude. In A. F. Healy; L. E. Bourne, Jr. (Eds.), Foreign language learning: Psycholinguistic studies on training and retention. Mahwah, NJ: Lawrence Erlbaum Associates, 1998, p. 339-364.

ORTEGA, L. Understanding second language acquisition. London: Arnold. 2009.

SALTHOUSE, T. A. The processing-speed theory of adult age differences in cognition. Psychological Review, 103, p. 403-428, 1996.

SCHNEIDER, W.; SHIFFRIN, R. M. Controlled and automatic human information processing I. Detection, search and attention. Psychological Review, v. 84, p. 1-66, 1977.

TOMITCH, L. M. B. Reading: Text Organization Perception and Working Memory Capacity. Florianópolis: PGI/UFSC. (Livro da série ARES - Advanced Research in English Series). 2003.

TRIOLA, M. F. Introdução à Estatística. 7a ed. Rio de Janeiro: LTC, 1999.

UNSWORTH, N.; ENGLE. R.W. The Nature of Individual Differences in Working Memory Capacity: Active Maintenance in Primary Memory and Controlled Search from Secondary Memory. Psychological Review, v. 114, n. 1, p. 104-132. 2007. 
WOOD, G., CARVALHO, M.R, NEVES, R., HAASE, V. Validação da Bateria de Avaliação da Memória de Trabalho (BAMT-UFMG). Psicologia: Reflexão e Crítica, v. 14, n. 2, p. 325341, 2001.

Recebido em março de 2014.

Aceito em maio de 2014. 